\title{
ACR IN DOLOMITIC AGGREGATE CONCRETE FOR AN AUTOGENOUS SELF-HEALING PROCESS
}

\section{VPLIV ACR-REAKCIJE NA AVTOGENO CELJENJE BETONOV Z DOLOMITNIM AGREGATOM}

\author{
Petra Štukovnik¹, Violeta Bokan Bosiljkov¹, Marjan Marinšek ${ }^{2 *}$ \\ ${ }^{1}$ University of Ljubljana, Faculty of Civil and Geodetic Engineering, Jamova 2, 1000 Ljubljana, Slovenia \\ ${ }^{2}$ University of Ljubljana, Faculty of Chemistry and Chemical Technology, Večna pot 113, 1000 Ljubljana, Slovenia
}

Prejem rokopisa - received: 2019-08-22; sprejem za objavo - accepted for publication: 2020-01-29

doi:10.17222/mit. 2019.196

This paper investigates the process of alkali-carbonate reaction (ACR) in dolomite aggregate concrete in view of its potential as a self-healing process. Samples for the ACR self-healing study were prepared using a cement composite with self-compacting properties in fresh state. The mixture was composed of Portland cement CEM I and typical Slovenian crushed dolomite aggregate in the role of aggregate and stone filler. Samples were subsequently exposed to accelerated testing conditions simulated by $1-\mathrm{M} \mathrm{NaOH}$ at $60^{\circ} \mathrm{C}$ or deionized water at $60^{\circ} \mathrm{C}$. The conducted research revealed that the complete ACR process was successfully triggered, including the dedolomitization and formation of secondary phases, i.e., $\mathrm{CaCO}_{3} \mathrm{called}^{\mathrm{c}} \mathrm{carbonate}$ halo", Ca-Al-involving phase and some minor phases containing Mg-Al, Mg-Si and/or Mg-Al-Si. Additionally, the "carbonate halo" and Ca-Al-involving phase also precipitated inside purposely preformed cracks in the samples. Smaller cracks up to $\approx 200$ $\mu \mathrm{m}$ in width were completely filled with the "carbonate halo" and Ca-Al-involving phase. Wider cracks may not have been completely filled with the newly precipitated phases; however, their length and width were also successfully reduced. With filling of the pores and cracks, the mechanical strength of the cement composite was increased substantially due to the ACR self-healing process.

Keywords: Alkali carbonate reaction (ACR), self-healing, dedolomitisation, formation of new phases, mechanical strength

Prispevek obravnava proces alkalno agregatne reakcije (ACR) v betonih $\mathrm{z}$ dolomitnim agregatom in vpliv te reakcije na proces »samoceljenja«. Za namen spremljanja avtogenega »samoceljenja je bil pripravljen cementni kompozit s samozgoščevalnimi lastnostmi v svežem stanju. Osnovne sestavine, ki smo jih uporabili pri izdelavi vzorcev, so: čisti Portlandski cement (CEM I), drobljen dolomitni agregat in dolomitna moka. Vzorci so bili izpostavljeni pospešenim pogojem staranja, ki so bili simulirani s pomočjo $1 \mathrm{M}$ raztopine $\mathrm{NaOH}$ oz. deionizirane vode pri temperaturi $60^{\circ} \mathrm{C}$. Predhodne preiskave so pokazale, da ACR reakcija poleg procesa dedolomitizacije vključuje tudi oblikovanje sekundarnih faz, med njimi sekundarnega $\mathrm{CaCO}_{3}$ imenovanega tudi "karbonatni halo", Ca-Al-faze ter Mg-Al, Mg-Si in/ali Mg-Al-Si faze. Analiza preiskovanih vzorcev je pokazala, da se je v predhodno oblikovanih razpokah obarjal "karbonatni halo" in faza, ki vključuje Ca-Al. Manjše razpoke širine do $\approx 200$ um sta ti fazi popolnoma zapolnili, pri razpokah večjih začetnih širin pa se je njihova širina učinkovito zmanjšala. Poleg tega proces ACR in posledično avtogeno "samo-celjenje" vpliva na mehanske lastnosti preiskovanih preizkušancev.

Ključne besede: Alkalno karbonatna reakcija (ACR), samocelejnje, dedolomitizacija, oblikovanje novih faz, mehanska trdnost

\section{INTRODUCTION}

Concrete is the most widely used construction material. It is mainly a combination of cement, aggregate (coarse and fine), and water. A high compressive strength, availability, durability, as well as compatible behaviour with reinforcement steel bars, low price, simple preparation and the possibility of casting in desired shapes and sizes make concrete the material of choice for many applications. Despite concrete's advantages, unfortunately it also has a strong tendency to form cracks. Cracks are one of the main causes of concrete's deterioration and decrease in durability. ${ }^{1}$

Treatments of cracks and pores in concrete are generally divided into passive and active treatments ${ }^{2}$. Passive treatments can only heal the surface cracks, whereas active methods can fill both the interior and exterior cracks. Passive treatments can also be made by

*Corresponding author's e-mail:

marjan.marinsek@fkkt.uni-lj (Marjan Marinšek) means of external coatings, such as the application of chemical mixtures and polymers. Although passive treatments are applicable to many existing concrete structures, they have various limitations that hinder their application (i.e., poor weather resistance, moisture sensitivity, low heat resistance, unsustainability, poor bonding with concrete, susceptibility to degradation and delamination with age, and different thermal expansion coefficients of concrete and sealers). On the other hand, active treatment techniques, which are also known as self-healing techniques, can operate independently in different conditions, regardless of the crack's position. A self-healing mechanism in concrete can be established using three main strategies:

(1) autogenous healing;

(2) encapsulation of polymeric material;

(3) microbial production of calcium carbonate.

Especially autogenous healing and healing through microbial activity have recently attracted a lot of attention, because polymeric materials do not behave the 
Table 1: Chemical composition of CEM I

\begin{tabular}{|c|c|c|c|c|c|c|c|c|c|}
\hline Oxide (\%) & $\mathrm{SiO}_{2}$ & $\mathrm{Al}_{2} \mathrm{O}_{3}$ & $\mathrm{Fe}_{2} \mathrm{O}_{3}$ & $\mathrm{CaO}$ & $\mathrm{MgO}$ & $\mathrm{Na}_{2} \mathrm{O}$ & $\mathrm{K}_{2} \mathrm{O}$ & $\mathrm{Cl}$ & $\mathrm{SO}_{3}$ \\
\hline & 20.31 & 4.49 & 3.25 & 63.72 & 1.53 & 0.26 & 0.6 & 0.05 & 0.75 \\
\hline
\end{tabular}

same as the cement concrete composites and, in some extreme conditions, they even cause the extension of existing cracks. ${ }^{2,3}$

Autogenous healing is the natural process of repairing cracks in concrete (and other cement composites) that can occur in the presence of moisture or water. It fills the cracks through the hydration of un-hydrated cement particles or the carbonation of dissolved calcium hydroxide..$^{2-8}$ The hydration of calcium oxide produces calcium hydroxide (Equation (1)), which can react with the carbon dioxide present in the atmosphere, resulting in the production of calcium carbonate (Equation (2)). Calcium carbonate is one of the most useful and versatile fillers to plug the voids, porosities and cracks in concrete.

$$
\begin{aligned}
\mathrm{CaO}+\mathrm{H}_{2} \mathrm{O} & \rightarrow \mathrm{Ca}(\mathrm{OH})_{2} \\
\mathrm{Ca}(\mathrm{OH})_{2}+\mathrm{CO}_{2} & \rightarrow \mathrm{CaCO}_{3}+\mathrm{H}_{2} \mathrm{O}
\end{aligned}
$$

With respect to the above-mentioned mechanism of self-healing in concrete, one also has to consider the alkali-carbonate reaction (ACR) in concrete prepared using dolomite aggregate grains. The basic concept of the ACR reaction can be described in brief as follows. ${ }^{9-15}$ Dolomite crystals, present in dolomite aggregates, interact with the alkali hydroxides from the pore solution causing its decomposition and the intergrowth of calcite and brucite (Equation (3)). The carbonate ions, released during the dedolomitisation, migrate into the hydrated cement paste and assist in the portlandite dissolution (Equation(3)). Subsequently, the released $\mathrm{Ca}^{2+}$ ions react with the carbonate ions to form a secondary calcite (carbonate halo) around the decaying aggregate grain. Some additional reactions may take place at the phase boundary of the decaying dolomite grains and the binding cement paste, i.e., the formation of hydrotalcite $\left(6 \mathrm{MgO} \cdot \mathrm{Al}_{2} \mathrm{O}_{3} \cdot \mathrm{CO}_{2} \cdot 12 \mathrm{H}_{2} \mathrm{O}\right)$ (Equation(5)), the formation of $\mathrm{Mg}$-silicate gel $\left(4 \mathrm{MgO} \cdot 6 \mathrm{SiO}_{2} \cdot 7 \mathrm{H}_{2} \mathrm{O}\right)$ (Equation6)), and its subsequent reaction with brucite and gibbsite into chlinochlore $\left(5 \mathrm{MgO} \cdot \mathrm{Al}_{2} \mathrm{O}_{3} \cdot 3 \mathrm{SiO}_{2} \cdot 4 \mathrm{H}_{2} \mathrm{O}\right)$ (Equation(7)).

$$
\begin{gathered}
\mathrm{CaMg}\left(\mathrm{CO}_{3}\right)_{2}+2 \mathrm{OH}^{-}{ }_{\text {aq }} \rightarrow \\
\mathrm{Mg}(\mathrm{OH})_{2}+\mathrm{CaCO}_{3}+\mathrm{CO}_{3}{ }^{2-}{ }_{\text {aq }} \\
\mathrm{Ca}(\mathrm{OH})_{2}+\mathrm{CO}_{3}{ }^{2-}{ }_{\text {aq }} \rightarrow \mathrm{CaCO}_{3}+2 \mathrm{OH}^{-}{ }_{\text {aq }} \\
6\left[\mathrm{CaMg}\left(\mathrm{CO}_{3}\right)_{2}\right]+2 \mathrm{Al}(\mathrm{OH})_{4}^{-}{ }_{\text {aq }}+8 \mathrm{OH}^{-}{ }_{\text {aq }}+4 \mathrm{H}_{2} \mathrm{O} \rightarrow \\
6 \mathrm{MgO} \cdot \mathrm{Al}_{2} \mathrm{O}_{3} \cdot \mathrm{CO}_{2} \cdot 12 \mathrm{H}_{2} \mathrm{O}+6 \mathrm{CaCO}_{3}+5 \mathrm{CO}_{3}{ }^{2-} \text { aq } \\
4 \mathrm{Mg}(\mathrm{OH})_{2}+6 \mathrm{H}_{2} \mathrm{SiO}_{4}{ }^{2-}{ }_{\text {aq }}+9 \mathrm{H}_{2} \mathrm{O} \rightarrow \\
4 \mathrm{MgO} \cdot 6 \mathrm{SiO}_{2} \cdot 7 \mathrm{H}_{2} \mathrm{O}+12 \mathrm{OH}^{-}{ }_{\text {aq }} \\
\left.4 \mathrm{MgO} \cdot 6 \mathrm{SiO}_{2} \cdot 7 \mathrm{H}_{2} \mathrm{O}+6 \mathrm{Mg} \mathrm{OH}\right)_{2}+4 \mathrm{Al}_{(\mathrm{OH})_{4}^{-} \text {aq }} \rightarrow \\
2\left[5 \mathrm{MgO} \cdot \mathrm{Al}_{2} \mathrm{O}_{3} \cdot 3 \mathrm{SiO}_{2} \cdot 4 \mathrm{H}_{2} \mathrm{O}\right]+4 \mathrm{OH}^{-}{ }_{\text {aq }}+11 \mathrm{H}_{2} \mathrm{O}
\end{gathered}
$$

Since the described reactions of ACR lead to the formation of new solid phases that precipitate in the vicinity of the decaying aggregate, one question arises. Namely, new solid phases must (and can) precipitate inside the empty space in the concrete, which may, in turn, result in the filling of pores and cracks. This question has been almost completely overlooked in the literature. However, since spontaneous crack filling is a self-healing mechanism, the idea of ACR as a potential self-healing process is worth addressing in detail.

\section{EXPERIMENTAL PART}

\subsection{Sample preparation}

The samples of self-compacting cement composite (cement mortar) for detailed investigations of the influence of ACR on the autogenic self-healing properties were prepared by using crushed dolomite aggregate and dolomite filler from a quarry in the south-eastern part of Slovenia. This type of dolomite stone is relatively pure. As a result of the mineralogical quantitative X-ray analysis it was revealed that dolomite represents as much as $98.1 \%$ of the mineral content in the used aggregate and filler, and calcite represents $\approx 1.9 \%$. As a hydraulic binder, Portland cement CEM I 42.5 N (EN 197 1) produced by the Slovenian cement plant Salonit Anhovo d.d. was used. The chemical composition of the cement is given in Table 1, while its Blaine specific surface area and density were $3520 \mathrm{~cm}^{2} \mathrm{~g}^{-1}$ and $3.11 \mathrm{~g} \mathrm{~cm}^{-3}$, respectively. The water-to-cement ratio $(w / c)$ of the cement composite was 0.45 , and to achieve the appropriate viscosity and flowability of the composite, commercial polycarboxylate superplasticizer was added in the amount of $0.6 \%$ with respect to the mass of fine particles (cement and stone filler).

After the casting of mortar bars with dimensions of $40 \times 40 \times 160 \mathrm{~mm}$, the samples were demoulded after one day. Subsequently, cracks inside the samples were created deliberately by means of applying a flexural load. The mortar bars were afterwards cured and hardened for $28 \mathrm{~d}$ in an environment with a relative humidity above $90 \%$ and a temperature of $20 \pm 1{ }^{\circ} \mathrm{C}$. At the age of $28 \mathrm{~d}$, they were exposed to accelerated testing conditions, simulated by a 1-M aqueous solution of $\mathrm{NaOH}$ at $60{ }^{\circ} \mathrm{C}$ or deionized water at $60{ }^{\circ} \mathrm{C}$.

Denotation of the samples consists of the letters $\mathrm{H}_{2} \mathrm{O}$ for deionized water or $\mathrm{NOH}$ for $1-\mathrm{M} \mathrm{NaOH}$ solution, respectively, followed by the number 60 for the ageing temperature, and finally the ageing time is given in days $(0 \mathrm{D}$ or $28 \mathrm{D})$, months $(3 \mathrm{M}$ or $6 \mathrm{M})$ or years $(1 \mathrm{Y})$. The denotation OD presents mortar bars with an age of 28 days, before they were exposed to accelerated ageing conditions. 


\section{Methods}

Electron microscopy involved using a FE SEM Zeiss Ultra Plus microscope equipped with an EDS Oxford X Max SDD $50 \mathrm{~mm}^{2} 106$ detector and INCA 4.145 X-ray microanalysis software. Microstructure characterizations of the samples were performed with a Hirox KH 3000 optical microscopy system. The compressive strength $(6$ parallel samples) of the mortar bars was determined periodically according to the EN $101511^{16}$ standard test, by using a hydraulic testing machine with a capacity of $500 \mathrm{kN}$.

\section{RESAULTS AND DICUSSION}

\subsection{Mechanical properties of aged concretes}

The autogenous self-healing capacity of concretes is already a well-described spontaneous process, where the dissolution of calcium hydroxide and a subsequent reaction with ambient $\mathrm{CO}_{2}$ to form $\mathrm{CaCO}_{3}$ is recognized as the most important contribution to the healing mechanism. ${ }^{4,7}$ On the other hand, very little is known from the literature about the potential healing capacity of the ACR. This is true despite the fact that basic reactions involved in the ACR mechanism are well described and are known to produce secondary solid phases, which precipitate in the aged concrete system..$^{8-11}$ The latter, by its definition, has the potential to fill the cracks (as well as the pores) within the concrete and thus with time increase its mechanical strength.

To verify if (and to what degree) the progressive ACR can influence the mechanical properties of an aged concrete system with dolomite aggregates, a series of compressive tests was conducted after various accelerated ageing periods, as shown in Figure 1. The sample prior to the ageing (sample 0D) is taken as a reference sample and its mean value of the compressive strength of $56.4 \mathrm{MPa}$ is taken as the reference value. It is apparent that there is a clear tendency in the compressive strength increase with ageing time. This is particularly evident if the mortar bars are aged in a $\mathrm{NaOH}$ solution, whereas it is less manifested in the $\mathrm{H}_{2} \mathrm{O}$ ageing environment. Such an observation is logical if one takes into account the fact

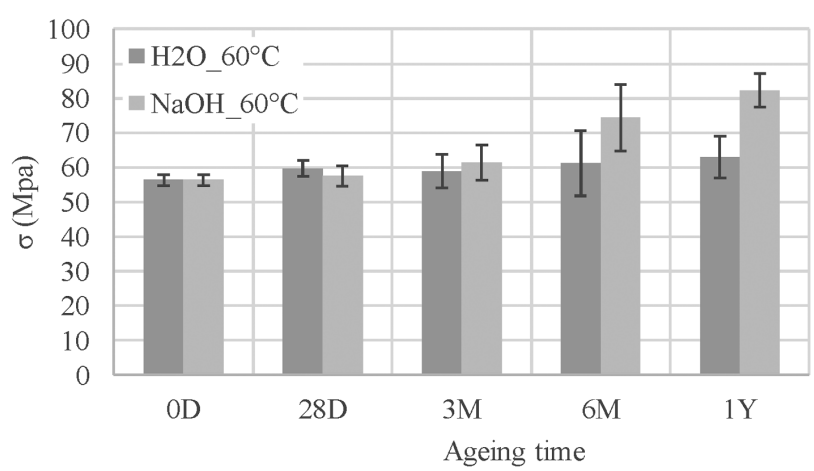

Figure 1: Compressive strength of aged mortar bars exposed to progressive ACR conditions that the ACR reaction system is triggered by $\mathrm{OH}^{-}$ions, meaning that the more alkaline the environment, the faster the ACR reactions. It was estimated in the literature that the $\mathrm{NaOH}$ environment accelerates the ACR reactions approximately 40-times when compared to the $\mathrm{H}_{2} \mathrm{O}$ environment. ${ }^{10}$ However, even in $\mathrm{H}_{2} \mathrm{O}$ environment the same set of reactions involved in the ACR reaction system should take place, meaning that eventually the result is the same, regardless of the ageing environment $\left(\mathrm{NaOH}\right.$ or $\left.\mathrm{H}_{2} \mathrm{O}\right)$.

In the $\mathrm{NaOH}$ environment the compressive strength of the mortar bars starts to increase relatively quickly after 3 months of aging. Thus, $3 \mathrm{M}, 6 \mathrm{M}$ or $1 \mathrm{Y}$ in the $\mathrm{NaOH}$-aged samples exhibit compressive strengths of 61.3 $\mathrm{MPa}, 74.3 \mathrm{MPa}$ or $82.3 \mathrm{MPa}$, respectively. This is $8.7 \%, 31.7 \%$ or $46 \%$, respectively, higher than the compressive strength of the reference sample. A pronounced increase in the compressive strength after 3 months of ageing is not surprising, since this is also the time period when the samples become visually and noticeably affected by the progressive ACR. In the $\mathrm{H}_{2} \mathrm{O}$ ageing environment, the final compressive strength is increased to $63 \mathrm{MPa}$, which is $11.7 \%$ more than the reference compressive strength. The observed clear increase of the compressive strength in the $\mathrm{H}_{2} \mathrm{O}$ - or (in particular) the $\mathrm{NaOH}$-aged mortar bars unambiguously corroborates the idea of the self-healing power of the ACR reaction system.

\subsection{Microstructure observations}

To better understand the observed tendency in the mechanical properties of the tested mortar bars, the microstructural changes in the aged concrete systems were simultaneously monitored. It appears that secondary $\mathrm{CaCO}_{3}$ (Equation(4)4) not only precipitates in the cement paste around the decaying aggregate (precipitation of secondary $\mathrm{CaCO}_{3}$ is well documented in the work of P. Štukovnik et al. ${ }^{10}$ ), but it also fills the preformed cracks in the concrete (Figures 2-4). Such crack filling is possible because $\mathrm{CO}_{3}{ }^{2-}$ aq and $\mathrm{Ca}^{2+}{ }_{\text {aq }}$ liberated

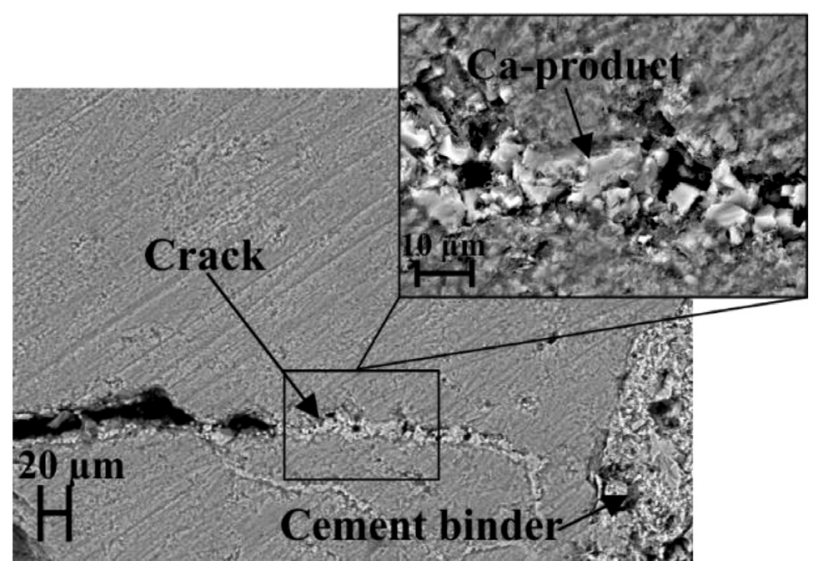

Figure 2: Self-healing in concrete due to the progressed ACR in the sample aged for 3 months in $\mathrm{NaOH}$ 


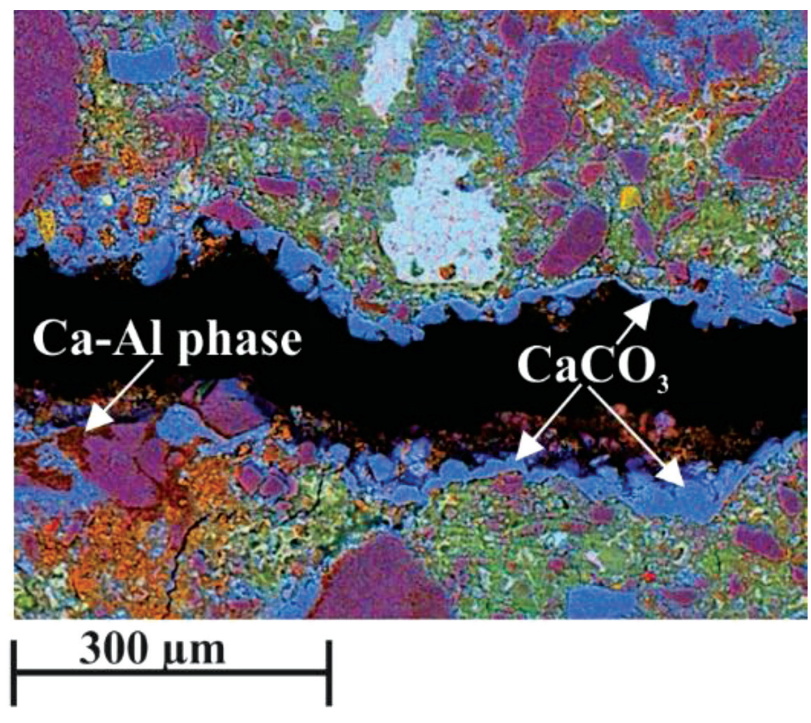

Figure 3: Self-healing of larger cracks in concrete due to the progressed ACR in the sample aged for 6 months in $\mathrm{NaOH}$

during the dedolomitization or Portlandite dissolution (Equations (3) and (4)) are mobile species in a wet environment. Consequently, they diffuse throughout the system and precipitate inside the free space found in the pores and/or cracks. In the $\mathrm{NaOH}$-aged concrete systems crack filling can be clearly observed already after 3 months of ageing (Figure 2). The progressing precipitation of the secondary calcite slowly reduces the length and width of the cracks and thus gradually recovers the mechanical strength of the concrete. The newly formed secondary calcite has the potential to completely fill the smaller preformed cracks (hair cracks). Larger cracks, on the other hand, may not be completely filled. Instead, they are just reduced in length and width by the precipitation of the new phases in the crack's outer rim (Figure 3). Thus, after 1 year of accelerating ageing in $\mathrm{NaOH}$, cracks with widths up to $\approx 200 \mu \mathrm{m}$ are found to be filled completely (Figure 4).

In the $\mathrm{H}_{2} \mathrm{O}$ environment, the progress of ACR is substantially slower. However, after 1 year of ageing, filling of some smaller cracks (up to $50 \mu \mathrm{m}$ in width) due to the ACR precipitating products may also be found in the $\mathrm{H}_{2} \mathrm{O}$ environment (Figure 5). At the same time, relatively large pores seem to be fairly unaffected by the ACR precipitating products.

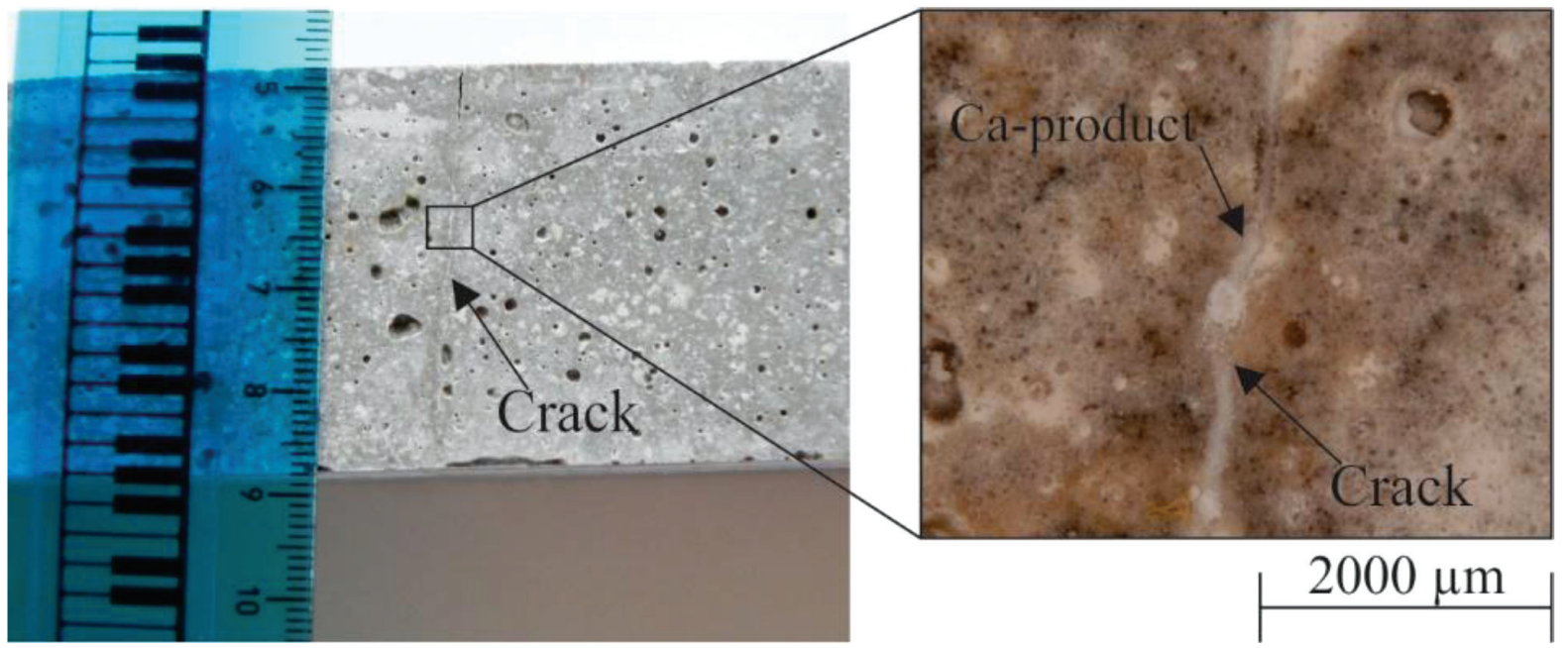

Figure 4: Complete healing of crack in concrete due to the ACR process (sample exposed in 1-M NaOH for 1 year)

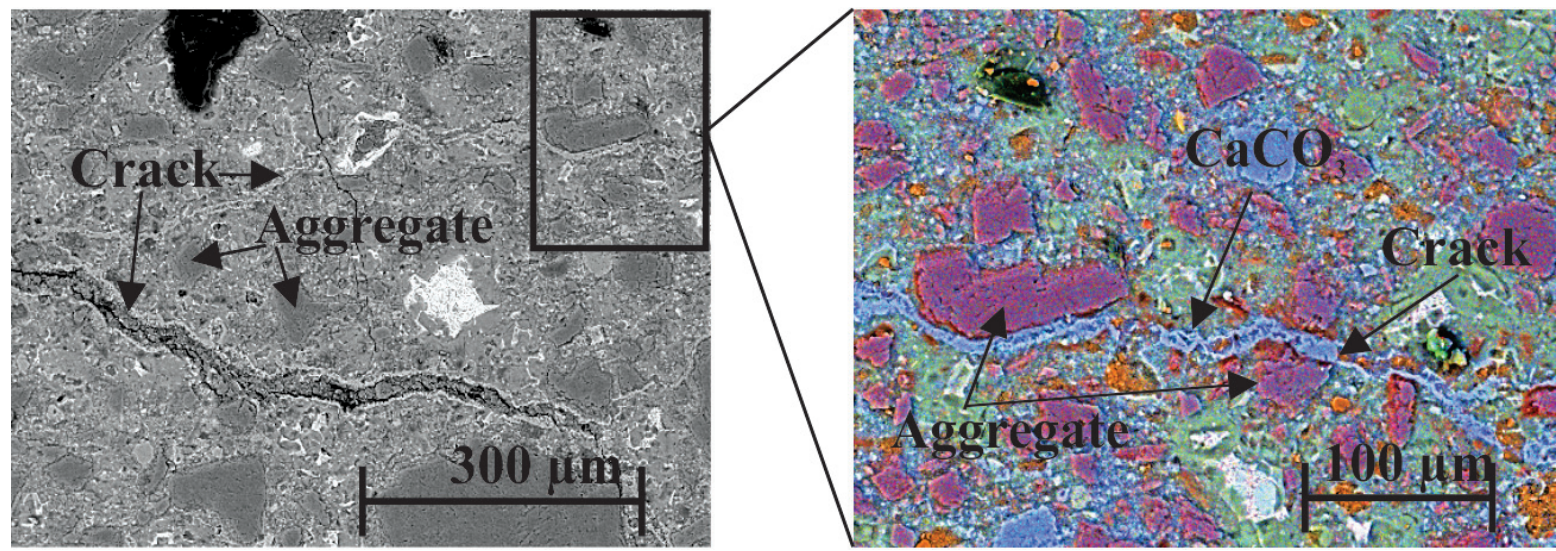

Figure 5: Self-healing in concrete due to the progressed ACR in the sample aged for 1 year in $\mathrm{H}_{2} \mathrm{O}$ 


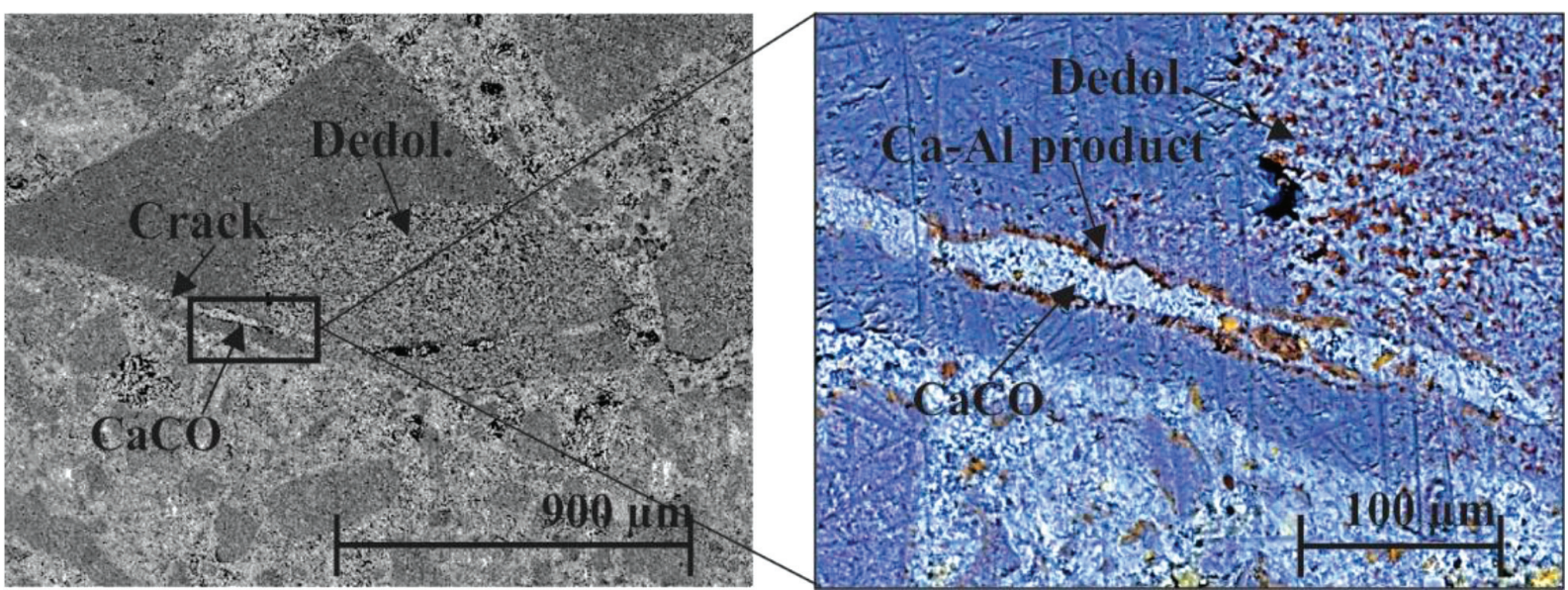

Figure 6: Formation of $\mathrm{CaCO}_{3}$ and $\mathrm{Ca}-\mathrm{Al}$-phase during cement composite self-healing (sample exposed to 1-M NaOH for 9 months)

Another distinguished newly formed solid phase during the ACR self-healing process, which may also precipitate in cracks, is the $\mathrm{Ca}-\mathrm{Al}$-involving phase. According to the EDS analysis this Ca-Al-involving solid phase has a $\mathrm{Ca}: \mathrm{Al}$ atomic ratio close to $2: 1$ and involves $\mathrm{C}$ (probably as carbonate). This chemical composition is characteristic for many of AFm phases, which are one of the main products formed during the hydration of the Portland and calcium-aluminate-cementbased systems. ${ }^{12}$ The exact composition of this new Ca-Al-involving solid phase still remains to be determined. However, at this point the strongest candidate is $3 \mathrm{CaO} \cdot \mathrm{Al}_{2} \mathrm{O}_{3} \cdot \mathrm{CaCO}_{3} \cdot 11 \mathrm{H}_{2} \mathrm{O}$. Precipitation of Al-involving phases requires a soluble Al-source. The presence of aluminate ions in concrete originates from the soluble nature of alumina involving minerals present in the cement (i.e., tricalcium aluminate $3 \mathrm{CaO} \cdot \mathrm{Al}_{2} \mathrm{O}_{3}$ and tetracalcium aluminoferrite $4 \mathrm{CaO} \cdot \mathrm{Al}_{2} \mathrm{O}_{3} \cdot \mathrm{Fe}_{2} \mathrm{O}_{3}$ ) under alkaline conditions. Their appearance may be illustrated on gibbsite $\left(\mathrm{Al}_{2} \mathrm{O}_{3} \cdot 3 \mathrm{H}_{2} \mathrm{O}\right)$ dissolution (Equation (8)). Aluminate ions then migrate and may be consumed in several reactions, including the formation of $\mathrm{AFm}$ phases.

$$
\mathrm{Al}_{2} \mathrm{O}_{3} \cdot 3 \mathrm{H}_{2} \mathrm{O}+2 \mathrm{OH}^{-}{ }_{\text {qq }}+\rightarrow 2 \mathrm{Al}(\mathrm{OH})_{4}^{-} \text {aq }
$$

The newly formed Ca-Al-phase precipitates in the crack's outer rim, as shown in Figures 3 and 6.

\section{CONCLUSIONS}

The most significant attributes of concrete are its compressive strength and durability. The obtained results regarding self-healing due to the progress of ACR in dolomitic aggregate concretes enable us to draw the following main conclusions:

- Advanced ACR causes the formation of new solid phases in concretes with dolomite aggregates. Phase transformations during the ACR are the same in the $\mathrm{NaOH}$ or aqueous environment.
- These new solid phases (predominantly $\mathrm{CaCO}_{3}$ and some Ca-Al-phases) precipitate in pores and potential cracks of concrete.

- Consequently, the ACR solid products alter the mechanical properties of the aged concrete. With progressive filling of the cracks and pores, compressive the strength of the concrete increases. Thus, the ACR acts as a self-healing mechanism.

- The ACR-based self-healing mechanism is able to completely heal cracks with widths up to č200 $\mu \mathrm{m}$ after 1 year in the $\mathrm{NaOH}$ environment. In the $\mathrm{H}_{2} \mathrm{O}$ environment, after 1 year only hair cracks may be filled with solid ACR products.

- The observed clear increase in the compressive strength in aged concrete samples unambiguously supports the self-healing power of the ACR reaction system.

\section{Acknowledgements}

The authors would like to acknowledge the financial support of the Slovenian Research Agency through research programmes P1-0175 and P2-0185, and research project J2-9196.

\section{REFERENCES}

${ }^{1}$ I. Galan, A. Baldermann, W. Kusterle, M. Dietzel, F. Mittermayr, Durability of shotcrete for underground support - Review and update, Construction and Building Materials, 202 (2019) 465-493

${ }^{2}$ E. Schlangen, S. Sangadji, Addressing Infrastructure Durability and Sustainability by Self Healing Mechanisms - Recent Advances in Self Healing Concrete and Asphalt, Procedia Engineering, 54 (2013) 39-57

${ }^{3}$ H. Huang, G. Ye, C. Qian, E. Schlangen, Self-healing in cementitious materials: Materials, methods and service conditions, Materials \& Design, 92 (2016) 499-511

${ }^{4}$ S. Sangadji, Can Self-healing Mechanism Helps Concrete Structures Sustainable?, Procedia Engineering, 171 (2017) 238-249

${ }^{5}$ K. Vijay, M. Murmu, S. V. Deo, Bacteria based self healing concrete - A review, Construction and Building Materials, 152 (2017) 1008-1014 


\section{P. ŠTUKOVNIK et al.: ACR IN DOLOMITIC AGGREGATE CONCRETE FOR AN AUTOGENOUS SELF-HEALING PROCESS}

${ }^{6}$ N. Hearn, Self-sealing, autogenous healing and continued hydration: What is the difference?, Materials and Structures, 31 (1998) 8, 563

${ }^{7}$ N. Hearn, C. T. Morley, Self-sealing property of concrete Experimental evidence, Materials and Structures, 30 (1997) 7, 404-411

${ }^{8}$ M. Sánchez, P. Faria, L. Ferrara, E. Horszczaruk, H. M. Jonkers, A Kwiecień, J. Mosa, A. Peled, A. S. Pereira, D. Snoeck, M. Stefanidou, T. Stryszewska, B. Zając, External treatments for the preventive repair of existing constructions: A review, Construction and Building Materials, 193 (2018) 435-452

${ }^{9}$ T. Katayama, The so-called alkali-carbonate reaction (ACR) - Its mineralogical and geochemical details, with special reference to ASR, Cement and Concrete Research, 40 (2010) 4, 643-675

${ }^{10}$ P. S?tukovnik, V. Bokan Bosiljkov, M. Marinšek, Microstructural changes in cement mortar due to an alkali-carbonate reaction, Mater. Tehnol., 53 (2019) 3, 425-432

${ }^{11}$ P. Štukovnik, V. Bokan Bosiljkov, M. Marinšek, Detailed investigation of ACR in concrete with silica-free dolomite aggregate, Construction and Building Materials, 216 (2019) 325-336
${ }^{12}$ F. Locati, D. Falcone, S. Marfil, Dedolomitization and alkali-silica reactions in low-expansive marbles from the province of Córdoba, Argentina. A microstructural and chemical study, Construction and Building Materials, 58 (2014) 0, 171-181

${ }^{13} \mathrm{G}$. Torraca, Lectures on Materials Science for Architectural Conservation, The Gette Institute, Los Angeles 2009, 193

${ }^{14} \mathrm{~V}$. Jensen, The controversy of alkali carbonate reaction: Stete of art on the reaction mechanisms and behaviour in concrete, J. H. I. T. Drimalas, B. Fournier Ed; 14th International Conference on Alkali-Aggregate Reactions in Concrete, Austin, Texas, USA, 2012, 10

${ }^{15}$ M. Radjonjic, et.al., Novel Techniques in a study of the mechanism of dedolomitisation in Alkali-Carbonate Reaction, Ed; Alkaliaggregate reaction : 11th international conference, Quebec, Canada, 2000, 99-108

${ }^{16}$ SIST, SIST EN 1015-11:2001. Methods of test for mortar for masonry - Part 11: determination of flexural and compressive strength of hardened mortar, (2001) 